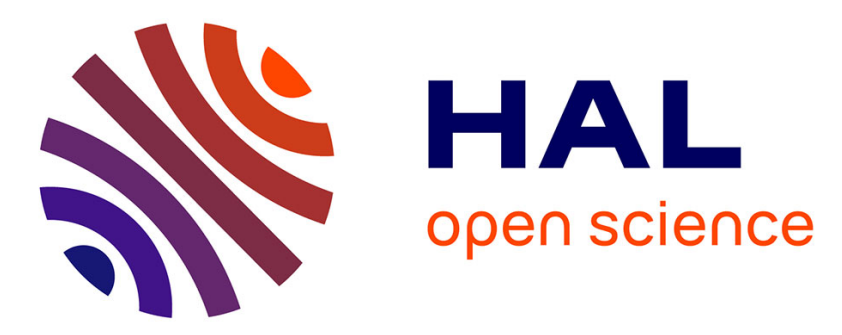

\title{
Binding capacities of different soil size fractions in the formation of herbicide-bound residues
}

\author{
Pierre Benoit, Enrique Barriuso, Valerie Bergheaud, Véronique Etiévant
}

\section{To cite this version:}

Pierre Benoit, Enrique Barriuso, Valerie Bergheaud, Véronique Etiévant. Binding capacities of different soil size fractions in the formation of herbicide-bound residues. Agronomie, 2000, 20 (5), pp.505-512. 10.1051/agro:2000145 . hal-00886056

\section{HAL Id: hal-00886056 https://hal.science/hal-00886056}

Submitted on 1 Jan 2000

HAL is a multi-disciplinary open access archive for the deposit and dissemination of scientific research documents, whether they are published or not. The documents may come from teaching and research institutions in France or abroad, or from public or private research centers.
L'archive ouverte pluridisciplinaire HAL, est destinée au dépôt et à la diffusion de documents scientifiques de niveau recherche, publiés ou non, émanant des établissements d'enseignement et de recherche français ou étrangers, des laboratoires publics ou privés. 
Original article

\title{
Binding capacities of different soil size fractions in the formation of herbicide-bound residues
}

\author{
Pierre Benoit*, Enrique Barriuso, Valérie Bergheaud, Véronique EtiÉvant
}

INRA, Unité Environnement et Grandes Cultures, BP 01, 78850 Thiverval-Grignon, France

(Received 16 September 1999; revised 20 December 1999; accepted 27 January 2000)

\begin{abstract}
A simplified particle-size fractionation procedure of soil organic matter was used to localize and quantify the non-extractable residues of ${ }^{14} \mathrm{C}$-labelled isoproturon in a soil where large amounts of bound residues were formed. Four size-fractions were isolated corresponding to non-humified organic matter in fractions (>200 and 200-50 $\mu \mathrm{m})$ and humified organic matter in fractions $(50-0.2 \mu \mathrm{m}$ and $<0.2 \mu \mathrm{m})$. The majority of ${ }^{14} \mathrm{C}$-isoproturon bound residues were associated with humified organic matter. In each fraction, concentrations of bound residues normalized to carbon $(\mathrm{C})$ content were used as indicators of the capacity of organic matter to bind herbicide residues. Binding capacities differed among size fractions, and were greater for the more decomposed organic materials located in fractions $<50 \mu \mathrm{m}$. Results were compared to previous data concerning atrazine residues and discussed in terms of the physico-chemical and microbial processes implicated in the binding properties of the different fractions.
\end{abstract}

bound residue / organic matter / isoproturon / atrazine / physical fractionation

Résumé - Capacités de différentes fractions granulométriques de sol dans la formation de résidus liés d'herbicide. Une procédure simplifiée de fractionement granulométrique de la matière organique a été utilisée pour localiser et quantifier les résidus non-extractibles de ${ }^{14} \mathrm{C}$-isoproturon dans un sol formant de grandes quantités de résidus liés. Quatre fractions ont été isolées correspondant à la matière organique non-humifiée (fractions > 200 et 200-50 $\mu \mathrm{m}$ ) et à la matière organique humifiée (fractions $50-0,2$ et $<0,2 \mu \mathrm{m}$ ). La majorité des résidus liés de ${ }^{14} \mathrm{C}$-isoproturon sont associées aux matières organiques humifiées. Pour chaque fraction, les concentrations de résidus liés exprimées par rapport à la quantité de carbone (C) servent d'indicateurs de la capacité de la matière organique de chaque fraction à former des résidus non-extractibles. Ces capacités diffèrent d'une fraction à l'autre et sont plus élevées pour la matière organique humifiée des fractions $<50 \mu \mathrm{m}$. Les résultats sont comparés à des données antérieures concernant l'atrazine et discutés en terme de processus physico-chimiques et microbiologiques impliqués dans la stabilisation de résidus d'herbicides.

résidu lié / matière organique / isoproturon / atrazine / fractionnement physique

Communicated by Isabelle Lamy

* Correspondence and reprints

benoit@grignon.inra.fr 


\section{Introduction}

In soils, most pesticides and other organic pollutants undergo several processes leading to their gradual disappearance or dissipation. A proportion of the xenobiotics entering the soil ecosystem may be eliminated through volatilization, plant uptake, leaching down the soil profile or lost by surface runoff. Some losses are caused by chemical reactions such as hydrolysis and oxidation, catalytic action of light, extracellular enzymes or clay minerals, whereas a major route of degradation is that of biotransformation and mineralization by soil microrganisms. Simultaneously to these different dissipation processes, a significant amount of xenobiotics and their transformation products persists in soil as non-extractable or bound residues. As these residues represent a potential environmental hazard, they have been the subject of much research during the last two decades $[8,14,20,21]$.

Although the absolute amounts of nonextractable residues first depend on the extraction procedures, there is sufficient evidence in the literature to assume that a fraction of the bound chemicals cannot be recovered by exhaustive extraction. As recently reviewed by Dec and Bollag [14], the formation of non-extractable residues may correspond to physical sequestration controlled by slow sorption processes and diffusion into some soil organic matter components [26], and to strong chemical bonds between the chemical and certain organic constituents, such as covalent binding by oxidative coupling and incorporation into humic polymers [17, 32]. Incorporation into soil microbial biomass represents another important route to the formation of non-extractable residues [29]; all of these mechanisms involve soil organic matter (SOM).

Chemical fractionation methods for SOM have been used to study the interactions between pesticides and soil organic constituents, mainly by measuring ${ }^{14} \mathrm{C}$ - labelled pesticide-bound residues in fulvic, humic and humin fractions $[8,11,20]$. More recently, such separation procedures have been used to isolate pesticide-bound residues in organic fractions for detailed investigation by ${ }^{13} \mathrm{C}$ - or ${ }^{15} \mathrm{~N}$ - NMR spectroscopy [14]. However, in such studies, alkaline extraction may introduce some artefacts since this can modify the chemical nature of the soil organic components and the pesticide molecules.

Therefore, physical methods based on particle size or density, which were initially developed to study soil organic matter dynamics $[1,13,16,30$, 31], have been also applied to study pesticide-SOM interactions. For such purposes, physical fractionation methods have been combined with chemical methods [2-4] or used alone [5]. These methods allow an efficient separation of fresh or less humified organic matter from humified organic matter; the former being localized in the coarser and the latter in the finer fraction usually $<50 \mu \mathrm{m}$. They offer a better conservation of the chemical nature of the organic materials and preserve to some extent the organo-mineral associations of the soil particles [13].

In this study, we used size fractionation techniques to study the formation of bound residues of isoproturon (3-(4-isopropylphenyl)-1,1-dimethylurea). This herbicide can rapidly form nonextractable residues, especially in soils with a high degrading activity [22]. In a previous study, we have demonstrated that large amounts of isoproturonbound residues were formed in a soil under a grassed strip, especially in the first few centimeters which contained greater amounts of plant residues [6]. The objectives of the present study were: (i) to localize non-extractable residues in different compartments of organic matter, mainly non-humified or poorly decomposed organic material derived from grass vegetation in the fractions coarser than $50 \mu \mathrm{m}$, and in the more humified organic matter fraction $<50 \mu \mathrm{m}$; (ii) to evaluate the binding capacities of the different isolated size fractions; and (iii) to compare the results to those of previous studies concerning another herbicide, atrazine (2-chloro-4(ethylamino)-6-(isopropylamino)-s-triazine) [3, 4, 7].

\section{Materials and methods}

\subsection{Soil}

The soil studied originated from the ITCF experimental site at la Jaillière (Loire Atlantique, France). 
It is a hydromorphic silt loam overlying schists of the Massif Armoricain with clay, silt and sand contents of 267,404 and $329 \mathrm{~g} \cdot \mathrm{kg}^{-1}$ respectively. Organic carbon $(\mathrm{C})$ and nitrogen $(\mathrm{N})$ contents were 21.8 and $2.39 \mathrm{~g} \cdot \mathrm{kg}^{-1}$ soil respectively (dry weight basis) on a bulk sample $(0-15 \mathrm{~cm})$, and the $\mathrm{pH}$ in water was 6.0. The soil was sampled from an experimental grassed buffer strip planted with perennial rye-grass (Lolium perenne) in 1992 [23]. Since then, the grassed strip has been managed as a permanent unfertilized grassland with two or three cuttings per year.

\subsection{Incubation with ${ }^{14} \mathrm{C}$-labelled isoproturon}

Samples were collected in April 1997. Undisturbed soil cores were sampled in polyvinyl chloride (PVC) columns containing approximatly $0.85 \mathrm{~kg}$ of soil $(7.5 \mathrm{~cm}$ diameter by $13 \mathrm{~cm}$ height). They were stored at $4{ }^{\circ} \mathrm{C}$ for one month before starting the incubation. After pre-wetting the soil columns at their water-holding capacity for $48 \mathrm{~h}$, ${ }^{14} \mathrm{C}$-ring-labelled isoproturon was applied to the top of the columns. The application rate was $0.14 \mathrm{mg} \cdot \mathrm{kg}^{-1}$ soil $\left(1.66 \mathrm{MBq} \cdot \mathrm{kg}^{-1}\right)$. Thereafter, three replicate columns were incubated in the dark at $18{ }^{\circ} \mathrm{C}$ for 1.5 months.

\subsection{Extraction and size-fractionation procedure}

After incubation, water extractable residues were eluted from the columns in a leaching experiment. A solution of $0.01 \mathrm{M} \mathrm{CaCl}_{2}$ was added in 50-mL increments to each column surface and percolating solutions were collected and analyzed for their ${ }^{14} \mathrm{C}$-content. The elution lasted $15 \mathrm{~d}$ until negligible radioactivity came out of the columns. After elution, soil cylinders were extruded out of the PVC at the appropriate depth and then progressively sectioned in four layers: 0-2, 2-4, 4-6 and 6-13 cm. Each layer was transferred to a centrifuge bottle, weighed and successively extracted twice with an aqueous solution of $0.01 \mathrm{M} \mathrm{CaCl}_{2}(2 \times 200$ $\mathrm{ml})$ to exhaust water-extractable ${ }^{14} \mathrm{C}$-isoproturon residues. Thereafter, soil layers were extracted three times with methanol $(3 \times 200 \mathrm{ml})$. Each extraction lasted $24 \mathrm{~h}$ with end-over-end shaking at room tem- perature. Extracts were recovered by centrifugation $(15 \mathrm{~min}$ at $5000 \mathrm{~g}$ ) and their radioactivity content was measured. After extraction, the soil contained in each layer was air-dried at room temperature and weighed. Aliquots were used for the determination of total bound residue content of unfractionated soil layers; the rest being used for the size fractionation.

For the fractionation of soil-bound residues, a simplified protocol was adapted from Barriuso et al. [3]. A 30-g aliquot of the surface soil layer was dispersed in $100 \mathrm{ml}$ of water in a centrifuge bottle and shaken for $24 \mathrm{~h}$. Two fractions (> 200) and (200$50 \mu \mathrm{m})$ were separated by sieving. Then the residual fractions were recovered by sedimentation $(50-0.2 \mu \mathrm{m})$ and by centrifugation after floculation in $0.01 \mathrm{M} \mathrm{CaCl}_{2}(<0.2 \mu \mathrm{m})$. For the coarsest fractions, light organic material was separated from heavier mineral sands by flotation in water; the light organic fraction was designated $(>200 \mu \mathrm{m})_{\mathrm{O}}$ and the corresponding mineral fractions $(>200 \mu \mathrm{m})_{\mathrm{M}}$. All fractions were air-dried at $40{ }^{\circ} \mathrm{C}$, weighed, ground in an agate mortar and kept for the analysis of $\mathrm{C}, \mathrm{N}$ and ${ }^{14} \mathrm{C}$-bound residues.

\subsection{Analytical procedures}

Total $\mathrm{C}$ and $\mathrm{N}$ of the different fractions were determined by dry combustion using a LECO model CR12 carbon analyzer and a LECO FP-228N analyzer. Total radioactivity of solid samples (size fractions and whole soils) was determined after combustion in a Sample Oxidizer 307 (Packard) followed by trapping the ${ }^{14} \mathrm{C}-\mathrm{CO}_{2}$ with Carbosorb (Packard) and liquid scintillation counting (Kontron Betamatic V counter).

\section{Results}

\subsection{Formation of ${ }^{14} \mathrm{C}$-bound residues of isoproturon}

After 1.5 months, bound residues of isoproturon in the whole soil column represented $89 \%$ of the applied amount. The distribution of ${ }^{14} \mathrm{C}$-isoproturon residues according to depth showed that $63 \%$ of the 
Table I. Organic C and total ${ }^{14} \mathrm{C}$-isoproturon-bound residue distribution through depth in soil columns after incubation and leaching.

\begin{tabular}{cccc}
\hline $\begin{array}{c}\text { Soil column layers } \\
(\mathrm{cm})\end{array}$ & $\begin{array}{c}\text { Organic C } \\
\left(\mathrm{g} \cdot \mathrm{kg}^{-1}\right)\end{array}$ & $\begin{array}{c}\text { Bound residues } \\
(\% \text { initial } \\
\left.\text { applied }{ }^{14} \mathrm{C}\right)\end{array}$ & $\begin{array}{c}\left(\mu \mathrm{g}{ }^{14} \mathrm{C} \text {-isoproturon }\right. \\
\text { equivalent })\end{array}$ \\
\hline $0-2$ & 25.6 & $63 \pm 5$ & $83 \pm 7$ \\
$2-4$ & 21.8 & $18 \pm 9$ & $23 \pm 12$ \\
$4-6$ & 20.3 & $5 \pm 4$ & $7 \pm 5$ \\
$6-13$ & 19.1 & $3 \pm 1$ & $3 \pm 2$ \\
\hline
\end{tabular}

applied radioactivity was found as bound residues in the upper 0-2-cm layer, corresponding to $83 \pm 7 \mu \mathrm{g}$ ${ }^{14} \mathrm{C}$-isoproturon equivalent (Tab. I). In the underlying layers of the columns, non-extractable residues represented $26 \%$ of the applied herbicide. In a previous study, bound residues were quantified in soils from the same site, but sampled under grass vegetation and under wheat crop. The main difference between the two situations was found in the SOM content of the $0-20 \mathrm{~cm}$ soil layer [6]. It was shown that the amount of isoproturon-bound residues was higher under grass vegetation. Moreover, bound residues decreased with depth in the grassed soil profile, and this was correlated with the decrease in SOM content. The relation between soil organic C (SOC) content and the proportion of isoproturon bound residues is illustrated in Figure 1.

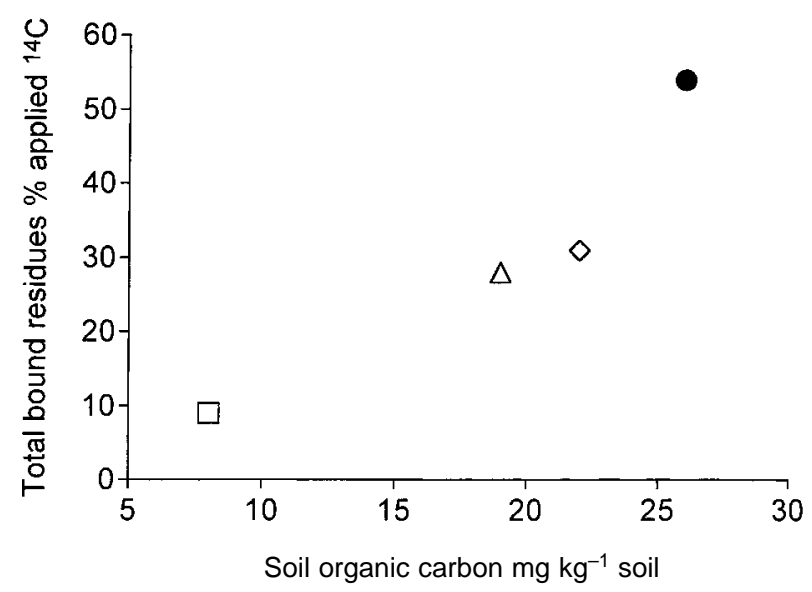

Figure 1. Relation between the proportion of ${ }^{14} \mathrm{C}$-non-extractable (bound) residues of isoproturon in whole (unfractionated) soils and soil organic $\mathrm{C}$ content. Results were taken from Benoit et al. [6]: $\square, \triangle, \diamond, \bullet$. The plain symbol represents the soil sampled in the present study.
Since the major proportion of the soil-bound residues formed in the columns was located in the first layer, we have focussed the soil-size fractionation study on this single layer. Therefore, the following results will examine the $0-2 \mathrm{~cm}$ organic layer.

\subsection{Distribution of organic matter in soil size fractions}

Organic $\mathrm{C}$ and $\mathrm{N}$ contents in the different soil size fractions are shown in Table II. The $(>200 \mu \mathrm{m})_{\mathrm{O}}$ fractions had the highest $\mathrm{C}$ content, i.e., $299 \mathrm{~g} \mathrm{C} \cdot \mathrm{kg}^{-1}$, corresponding to non-humified organic matter and mainly partially decomposed plant residues. More decomposed or humified organic matter located in fractions $<50 \mu \mathrm{m}[1,30]$ had a similar $\mathrm{C}$ content to the fraction 200-50 $\mu \mathrm{m}$. The decrease in the $\mathrm{C} / \mathrm{N}$ ratio with decreasing particle size showed the higher degree of decomposition in the small-size fractions and the incorporation of microbial biomass-derived materials in these fractions. The incorporation of $\mathrm{N}$ was particularly strong in the fine size fractions of this soil (Tab. II), indicating the rapid turn over of organic materials arising from the rhizospheric activity under grassland $[10,18,28]$.

The $\mathrm{C}$ balance showed that humified organic matter identified as fractions $<50 \mu \mathrm{m}$ represented $72 \%$ of the total organic matter. A large proportion of soil $\mathrm{C}$ was found in the $(>200 \mu \mathrm{m})_{\mathrm{O}}$ fraction, representing up to $16 \%$ of the SOC but only $1.9 \%$ of the soil weight (Fig. 2). This contrasted with results reported from cultivated soils, where the silt and clay fractions can represent up to $90 \%$ of the SOC $[1,10,16]$. This was explained by the large input of $\mathrm{C}$ derived from above-ground (shoots and leaves) and below ground (roots) plant material.

Table II. Organic C and N content of soil-size fractions.

\begin{tabular}{lccccc}
\hline \multicolumn{5}{c}{ Soil-size fractions $(\mu \mathrm{m})$} \\
\hline & $(>200 \mu \mathrm{m})_{\mathrm{O}}$ & $(>200 \mu \mathrm{m})_{\mathrm{M}}$ & $200-50$ & $50-0.2$ & $<0.2$ \\
\hline $\begin{array}{l}\mathrm{C} \text { content } \\
\left(\mathrm{g} \cdot \mathrm{kg}^{-1} \text { fraction }\right)\end{array}$ & 299 & 2 & 35 & 35 & 30 \\
$\mathrm{~N} \mathrm{content}$ & & & & & \\
$\left(\mathrm{g} \cdot \mathrm{kg}^{-1}\right.$ fraction $)$ & 13.9 & 0.1 & 2.0 & 4.7 & 4.1 \\
$\mathrm{C} / \mathrm{N}$ & 21.5 & 20 & 17.5 & 7.5 & 7.4 \\
\hline
\end{tabular}




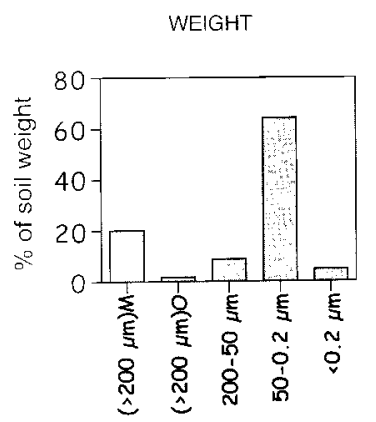

fractions

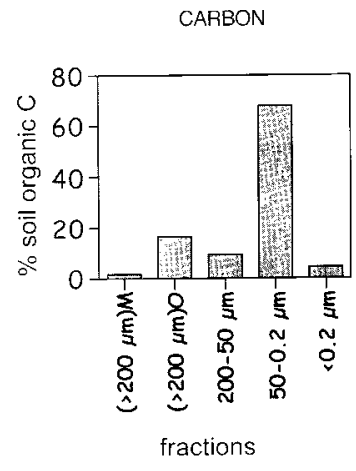

Figure 2. Distribution of soil mass and soil organic C according to size fractions.

\subsection{Distribution of ${ }^{14} \mathrm{C}$-isoproturon residues in soil size fractions}

The largest concentration of isoproturon-bound residues was found in the $(>200 \mu \mathrm{m})_{\mathrm{O}}$ fraction (Fig. 3). The 200-50 $\mu \mathrm{m}$ fraction had a lower concentration of ${ }^{14} \mathrm{C}$-isoproturon equivalent than the humified fractions, i.e., $50-0.2 \mu \mathrm{m}$ and $<0.2 \mu \mathrm{m}$. Concentrations of bound residues were expressed in relation to the $\mathrm{C}$ content of each fraction (Fig. 4).

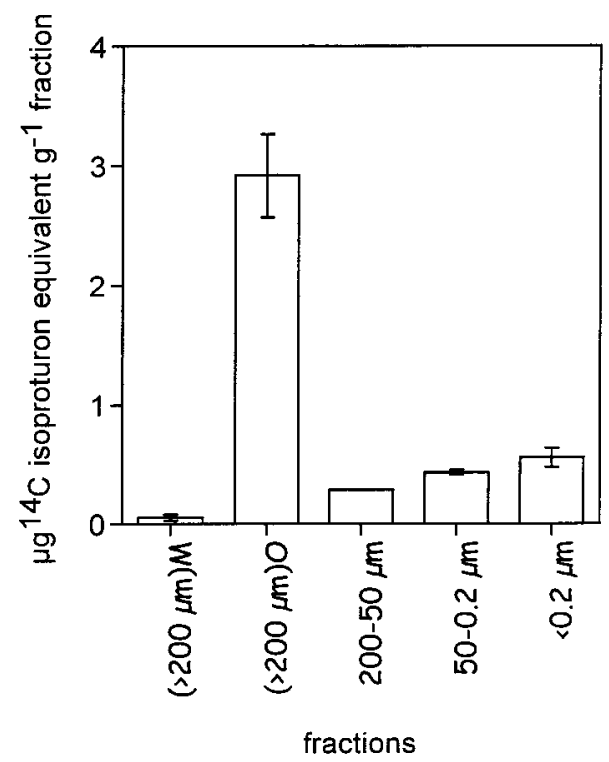

Figure 3. Contents of ${ }^{14} \mathrm{C}$-isoproturon bound residues in the different soil size fractions. Results are expressed in $\mu \mathrm{g}$ pesticide equivalent per $\mathrm{g}$ fraction. $\mu{ }^{14} \mathrm{C}$-isoproturon equivalent $\mathrm{g}^{-1} \mathrm{C}$ fraction

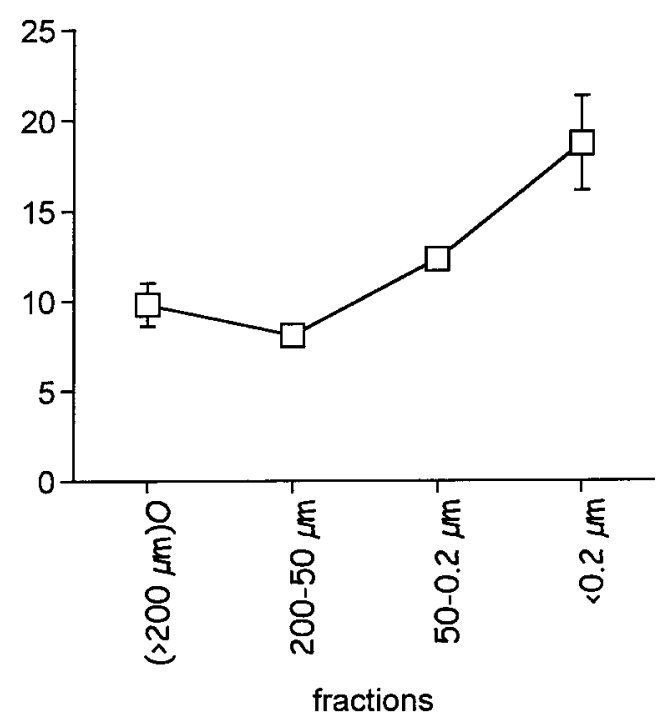

Figure 4. Contents of ${ }^{14} \mathrm{C}$-isoproturon bound residues in the different soil size fractions normalized to organic $\mathrm{C}$ content of each fraction. Results are expressed in $\mu \mathrm{g}$ pesticide equivalent per g $\mathrm{C}$ fraction.

Humified organic matter, especially in the $<0.2-\mu \mathrm{m}$ fraction, had the highest capacity to form bound residues. Although soil size fractionation separated only one single fraction in the range 50-0.2 $\mu \mathrm{m}$, the binding capacity of SOM for isoproturon residues increased with decreasing particle size.

The contribution of bound residues from each size fraction to the total soil-bound residues was calculated using the bound residue concentration and the mass proportion of each size fraction (Tab. III).

Table III. Amounts of ${ }^{14} \mathrm{C}$-isoproturon bound residues in soilsize fractions.

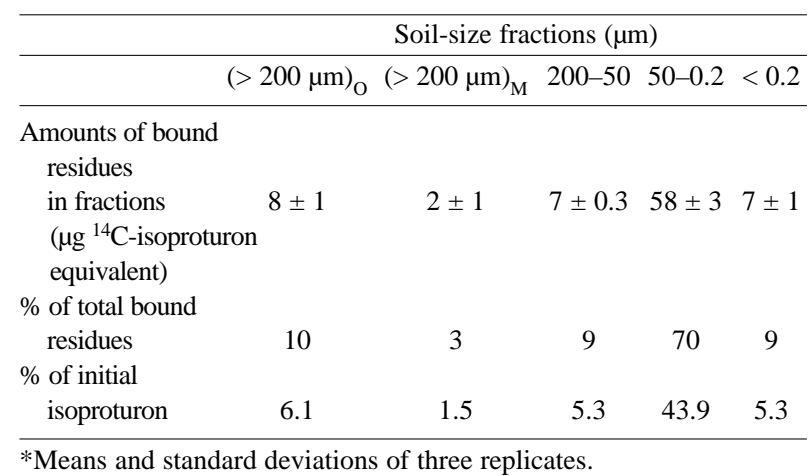

*Means and standard deviations of three replicates. 
The largest quantities of isoproturon-bound residues were associated with the humified organic matter. As a whole, humified SOM in the $<50-\mu \mathrm{m}$ fractions contained $79 \%$ of the total isoproturonbound residues, since 70 and $9 \%$ of the total isoproturon-bound residues were found in the 50-0.2 and $<0.2-\mu \mathrm{m}$ fractions, respectively. These amounts corresponded respectively to 43.9 and $5.3 \%$ of the initially applied isoproturon. The contribution of nonhumified organic matter in the $(>200 \mu \mathrm{m})_{\mathrm{O}}$ and 200-50 $\mu \mathrm{m}$ fractions represented 10 and $9 \%$ of the total isoproturon-bound residues, respectively.

\section{Discussion}

The majority of non-extractable isoproturonbound residue was associated with fraction $<50 \mu \mathrm{m}$ containing humified organic matter. Similar results have been obtained for atrazine in previous studies using similar particle-size fractionation procedures but with different soils and experimental conditions $[3,4,7]$. Differences in isoproturon bound residue contents among fractions indicated different binding capacities of the SOM present in size fractions. In particular, bound residue contents normalized to the $\mathrm{C}$ content of each size fraction clearly suggested that humified organic matter $(<50 \mu \mathrm{m})$ and nonhumified organic matter $\left((>200 \mu \mathrm{m})_{\mathrm{O}}\right.$ and 200-50 $\left.\mu \mathrm{m}\right)$ had different binding capacities for isoproturon residues (Fig. 4).

First, binding capacities may differ due to differences in the chemical nature of SOM among size fractions. With decreasing size of the fractions, increased decomposition of SOM is related to a greater hydrophobicity related to the increase in alkyl C during decomposition [12, 16]. This factor would enhance sorption of herbicides such as atrazine and isoproturon. As recently discussed by Piccolo et al. [25], hydrophobic interactions and conformational changes in the aliphatic portions of humic matter may be decisive in controlling desorption of atrazine. Simultaneously, strong interactions can be enhanced due to the increased density of reactive sites such as carboxylic and aromatic structures. This effect would be greater in fine fractions containing more reactive sites for binding attributed to aliphatic, carboxylic and aromatic C. This was corroborated by the larger proportion of ${ }^{14} \mathrm{C}$-isoproturon-bound residues found in the $<50-\mu \mathrm{m}$ fraction. However, previous results obtained for atrazine suggested that chemical changes in the organic matter during humification were not the only reason for the stabilization of atrazine residues in non-extractable forms. Indeed, concentrations of atrazine bound residues found in the $(>200 \mu \mathrm{m})_{\mathrm{O}}$ and $200-50 \mu \mathrm{m}$ fractions were greater than in humified matter isolated in finer fractions $<50 \mu \mathrm{m}[3,4]$.

An explanation proposed in these previous studies was that associations of more humified compounds with minerals in fractions $<50 \mu \mathrm{m}$ would have decreased their accessibility for binding reactions with atrazine [3]. On the contrary, organic materials present in the coarsest fractions would have a greater accessibility for physico-chemical interactions with atrazine. Results obtained with isoproturon showed, however, that organo-mineral associations recovered in the finest fractions could contain large concentrations of bound residues. Concerning this herbicide, several pieces of evidence in the literature suggest that the formation of bound residues is related to an extensive biodegradation $[15,22,24]$. In the same soil, we have previously shown that large amounts of degradation byproducts are formed [6]. Among the detected metabolites, 4-isopropylaniline was predominant in the surface layer of the grassed soil. Aniline derivatives are highly reactive degradation products of phenylurea herbicides which can bind covalently with humic substances $[9,27,32]$. Therefore, we assumed that covalent bonding of such derivatives was enhanced as a result of high microbial and exoenzymatic activities in the grassed soil of la Jaillière [6]. In grassed soils, production of root exudates and rhizospheric microbial activity are important factors enhancing the formation of organo-mineral associations $[18,30]$. Therefore, we also assume that a large proportion of the ${ }^{14} \mathrm{C}$-isoproturon residues associated with the silt or clay fractions was located within soil aggregates, which 
were disrupted during soil dispersion. In relation with the microbial activity in the grass rhizosphere, a significant proportion of the $\mathrm{C}$ in these fractions should correspond to microbially derived C $[16,18]$.

The accumulation of herbicide residues in the coarsest fractions may finally correspond to a bioaccumulation in soil microorganisms, mainly soil fungi, which may predominate in these size fractions [30]. This hypothesis was proposed to explain the greater concentrations of ${ }^{14} \mathrm{C}$-atrazinebound residues in non-humified fractions [3, 4]. In the latter study, this was supported by the presence of large amounts of dealkylated derivatives found in methanol extracts from the $(>200 \mu \mathrm{m})_{\mathrm{O}}$ fraction [3]; fungal degradation being frequently limited to dealkylation without further breakdown of the triazinic ring [19].

In conclusion, the different patterns of distribution of herbicide bound residues among sizefractions showed that chemical changes and the presence of microorganisms associated with decomposition of organic materials were both involved in the accumulation of bound residues. In this grassed soil, the stabilization of isoproturon residues was mainly explained by the strong reactivity of aniline degradation products [6]. Hence, the greater concentrations of isoproturon-bound residues in the finest fractions was explained by the formation of those metabolites able to form covalent bonds with humified organic matter, which was preferentially located in the fine fractions. Such transformation products were possibly accumulated in microbially derived $\mathrm{C}$, also preferentially localized in fractions $<50 \mu \mathrm{m}$. Concerning atrazine, greater concentrations of bound residues in less humified organic matter were attributed to two different mechanisms: bioaccumulation in fungal hyphae, and irreversible sorption of atrazine or its degradation products on decomposing plant material [3]. For both herbicides, higher concentrations of non-extractable residues were related to microbial transformation occurring after sorption and enhancing their irreversible binding. Regarding this last point, the accessibility of organic matter for both physico-chemical interactions and microbial trans- formations should be investigated more carefully in relation with the dynamics of soil aggregate formation to determine the binding capacities of the different SOM components.

Acknowledgements: This work was funded by the DGER of the French Ministry of Agriculture.

\section{References}

[1] Andreux F., Bruckert S., Correa A., Souchier B., Sur une méthode de fractionnement physique et chimique des agrégats des sols: origines possibles de la matière organique des fractions obtenues, C. R. Acad. Sci. 291D (1980) 381-384.

[2] Andreux F., Schiavon M., Bertin G., Portal, J.M., Barriuso E., The usefulness of humus fractionation methods in studies about the behaviour of pollutants in soils, Toxicol. Environ. Chem. 31/32 (1991) 29-38.

[3] Barriuso E., Koskinen W.C., Incorporating nonextractable atrazine residues into soil size fractions as a function of time, Soil Sci. Soc. Am. J. 60 (1996) $150-157$.

[4] Barriuso E., Schiavon M., Andreux F., Portal J.M., Localization of atrazine non-extractable (bound) residues in soil size fractions, Chemosphere 22 (1991) 1131-1140.

[5] Barriuso E., Andreux F., Schiavon M., Portal J.M., Intérêts et limitations des méthodes de séparation des micropolluants organiques, Sci. Sol 29/4 (1991) 301-320.

[6] Benoit P., Barriuso E., Vidon P., Réal B., Isoproturon sorption and degradation in a soil from grassed buffer strip, J. Environ. Qual. 28 (1999) 121-129.

[7] Bergheaud V., Barriuso E., Chone T., Schiavon M., Cinétiques d'incorporation de résidus d'atrazine dans la matière organique de fractions granulométriques d'un sol, C. R. XXII ${ }^{\mathrm{e}}$ Congr., Groupe Français des Pesticides, Dijon, France, 1992.

[8] Bertin G., Schiavon M., Les résidus non extractibles de produits phytosanitaires dans les sols, Agronomie 9 (1989) 117-124.

[9] Bollag J.-M., Myers C.J.M., Minard R.D., Biological and chemical interactions of pesticides with soil organic matter, Sci. Total Environ. 123/124 (1992) 205-217. 
[10] Cambardella C.A., Elliot E.T., Carbon and nitrogen distribution in aggregates from cultivated and native grassland soils, Soil Sci. Soc. Am. J. 57 (1993) 1071-1076.

[11] Capriel P., Haisch A., Khan S.U., Distribution and nature of bound (non-extractable) residues of atrazine in a mineral soil nine years after herbicide application, J. Agric. Food Chem. 33 (1985) 567-569.

[12] Capriel P., Beck T., Borchert H., Gronholz J., Zachmann G., Hydrophobicity of the organic matter in arable soils, Soil Biol. Biochem. 27 (1995) 1453-1458.

[13] Christensen B.T., Physical fractionation of soil and organic matter in primary particle size and density separates, Adv. Soil Sci. 20 (1992) 1-90.

[14] Dec J., Bollag J.-M., Determination of covalent and noncovalent binding interactions between xenobiotic chemicals and soil, Soil Sci. 162 (1997) 858-874.

[15] Gaillardon P., Sabar M., Changes in the concentration of isoproturon and its degradation products in soil and soil solution during incubation at two temperatures, Weed Res. 34 (1994) 243-250.

[16] Golchin A., Oades J.M., Skjemstad J.O., Clarke P., Structural and dynamic properties of soil organic matter as reflected by ${ }^{13} \mathrm{C}$ natural abundance, pyrolysis mass spectrometry and solid-state ${ }^{13} \mathrm{C}$ NMR spectroscopy in density fractions of an oxisol under forest and pasture, Aust. J. Soil Res. 33 (1995) 59-76.

[17] Hatcher P.G., Bortiatynski J.M., Minard R.D., Dec J., Bollag J.-M., Use of high-resolution ${ }^{13} \mathrm{C}$ NMR to examine the enzymatic covalent binding of ${ }^{13} \mathrm{C}$-labelled 2,4-dichlorophenol to humic substances, Environ. Sci. Technol. 27 (1993) 2098-2103.

[18] Jastrow J.D., Soil aggregate formation and the accrual of particulate and mineral-associated organic matter, Soil Biol. Biochem. 28 (1996) 665-676.

[19] Kaufman D.D., Blake J., Degradation of atrazine by soil fungi, Soil Biol. Biochem. 2 (1970) 73-80.

[20] Khan S.U., Bound pesticide residues in soil and plants, Residues Rev. 84 (1982) 1-25.

[21] Lichtenstein E., Katan J., Anderegg B.N., Binding of "persistent" and "non persistent" ${ }^{14} \mathrm{C}$-labelled insecticides in an agricultural soil, J. Agric. Food Chem. 25 (1977) 43-47.

[22] Lehr S., Glassgen W.E., Sandermann H. Jr., Beese F., Scheunert I., Metabolism of isoproturon in soils originating from different agricultural management systems and in cultures of isolated bacteria, Int. J. Environ. Anal. Chem. 65 (1996) 231-243.

[23] Patty L., Réal B., Gril J.J., The use of grassed buffer strips to remove pesticides, nitrate and soluble phosphorus compounds from runoff water, Pestic. Sci. 49 (1997) 243-251.

[24] Perrin-Ganier C., Schiavon M., Portal J.M., Babut M., Dégradation de l'isoproturon et disponibilité de ses résidus dans le sol, Weed Res. 35 (1995) 257-263.

[25] Piccolo A., Conte P., Scheunert I., Paci M., Atrazine interactions with soil humic substances of different molecular structure, J. Environ. Qual. 27 (1998) 1324-1333.

[26] Pignatello J.J., Xing B., Mechanisms of slow sorption of organic chemicals to natural particles, Environ. Sci. Technol. 30 (1996) 1-11.

[27] Reuter S., Ilim M., Munch J.C., Andreux F., Scheunert I., A model for the formation and degradation of bound residues of the herbicide ${ }^{14} \mathrm{C}$-isoproturon in soil, Chemosphere 39 (1999) 627-639.

[28] Sparling G.P., Kettles H.K., Shepherd T.G., Changes in soil organic $\mathrm{C}$, microbial $\mathrm{C}$ and aggregate stability under continuous maize and cereal cropping, and after restoration to pasture in soils from the Manawatu region, New Zealand, Soil Till. Res. 24 (1992) 225-241.

[29] Stott D.E., Martin J.P., Focht D.D., Haider K., Biodegradation, stabilization in humus, and incorporation into soil biomass of 2,4-D and chlorocatechol carbons, Soil Sci. Soc. Am. J. 47 (1983) 66-70.

[30] Tisdall J.M., Oades J.M., Organic matter and water-stable aggregates in soils, J. Soil Sci. 33 (1982) 141-163.

[31] Turchenek L.W., Oades J.M., Fractionation of organo-mineral complexes by sedimentation and density techniques, Geoderma 21 (1979) 311-343.

[32] Thorn K., Pettigrew P.J., Goldenberg W.S., Weber E.J., Covalent binding of aniline to humic substances. 2. 15N NMR studies of nucleophilic addition reactions, Environ. Sci. Technol. 30 (1996) 2764-2775. 